Jurnal Keperawatan Padjadjaran /Padjadjaran Nursing Journal

ISSN 2338-5324 (print)

ISSN 2442-7276 (online)

Online di http://jkp.fkep.unpad.ac.id

DOI : $10.24198 / \mathrm{jkp}$

\title{
The Origin and Development of Grounded Theory: A Brief History
}

\author{
Henny Suzana Mediani \\ Faculty of Nursing, Universitas Padjadjaran \\ Email :hennymediani@gmail.com
}

Submitted: 20-2-2018 Accepted: 30-4-2018 Published: 30-4-2018

\begin{abstract}
Grounded theory is an inductive research method that provides for the systematic generation of theory using qualitative or/and quantitative data generated from interviews, observation, or written sources such as documents, or some combination there of gained by a rigorous research method. Nowadays there has been much used of grounded theory as qualitative methodology in nursing and other health disciplines, Grounded theory has been an important methodology for nursing research. The aim of this brief article is to explain how grounded theory came about.
\end{abstract}

Keywords: Glaser, grounded theory, nursing, qualitative research. 
Henny Suzana : The Origin and Development of Grounded Theory: A Brief History

\section{Introduction}

In recent years the grounded theory has been growing popularity in the world and a rise in the use of grounded theory (GT) method as an approach in qualitative research, and is often used in disciplines such as nursing. There are thousands of publications of studies using grounded theory methods and seminal texts that can be used by researchers and doctorate students to guide their study and ensure the rigour of their research. Among the various methods of qualitative data analysis, grounded theory provides researcher with unique tool for theoretical development (Mediani, 2017; Jones, 2005). The aim of this short methodological review is to explain the historical overview, evolution of grounded theory, theoretical, and philosophical roots of grounded theory which is useful for novice researchers. The paper can be read with my previous paper, "An Introduction to Classical Grounded Theory” (Mediani, 2017).

\section{What is grounded theory method?}

Grounded theory is known as an inductive, comparative methodology that provides systematic guidelines for gathering, synthesizing, analyzing, and conceptualizing qualitative data for the purpose of theory construction that explains, at a broad conceptual level, a process, an action, or interaction about a substantive topic (Glaser \& Strauss, 1967; Strauss \& Corbin, 1990; Charmaz, 2000). Meanwhile, according to Glaser $(1978,1992,1998)$ Grounded Theory is a general research method that provides for the systematic generation of theory from data obtained by a rigorous research method. As a general methodology, grounded theory can use either qualitative data of any type such as video, images, text, observations, interviews etc or quantitative data, or a combination of these (Glaser, 1978, 1992, 1998). The key point here is that theory generated is grounded in the data.

Grounded theory differs from other various qualitative methods for two reasons, (1) "it is unencumbered by explicit expectations about what the research might find, or by personal beliefs and philosophies" (Pole \& Lampard, 2002, p.206), therefore allowing the researcher to formulate discoveries without prior knowledge, and (2) "It is an approach that leaves itself open to charges of relativism" (Pole \& Lampard, 2002, p.206), meaning that the results and theoretical assumptions are not uniquely valid (Jones, 2005). Grounded theory is known as a tool for analysis social phenomena, particularly when there is little known about the situation under investigation (Glaser \& Strauss, 1967). Using grounded theory provides the advantage of investigating an unknown area, to see what real social problems identified. It is therefore, will provides researcher with an opportunity to gather data inform the research and consequently developing the theoretical principles that are relevant to the situation under investigation, rather than the converse relationship which is more normally used with the conventional methods (Jones, 2005).

\section{Historical overview of discovery of grounded theory}

The grounded theory approach is both a way to do qualitative research and a way to create inductive theory (Glaser \& Strauss, 1967; Mediani, 2017). The grounded theory was first developed during the 1960s by American sociologists Barney Glaser and Anselm Strauss (Artinian, 2009; Glaser, 1992; Strauss \& Corbin, 1990). At that time, grand theory (logic-deductive theorising) and theory testing (verification) were the predominant approaches to knowledge development (Glaser \& Strauss, 1967). As sociologists, Glaser and Strauss felt driven by the lack of rigour and theoretical grounding in social science studies, and by the criticisms directed to qualitative research by those who considered quantitative studies to be the only viable means of enquiry (Hallberg, 2006). The two theorists came from different philosophical and research backgrounds and had made equally important contributions towards the creation of the grounded theory (Glaser, 1992; Wuest, 2012). Anselm Strauss graduated from the University of Chicago, which specialised in qualitative research and symbolic interactionism, and he was influenced by pragmatist writings. His training and fields of interest contributed to the grounded theory method. He was trained 
Henny Suzana : The Origin and Development of Grounded Theory: A Brief History

in symbolic interactionism by Herbert Blumer and Everett Hughes, a school of thought where strong tradition emphasised the importance of interaction between human behaviour and social roles (Blumer, 1969; Hallberg, 2006; Walker \& Myrick, 2006). On the other hand, Barney Glaser came from a tradition of quantitative research at Columbia University, where he developed an inductive perspective that combined both quantitative and qualitative research (Hallberg, 2006; McCann \& Clark, 2003; Walker \& Myrick, 2006). This perspective embraced the importance of theory generation from the perspective of participants (Creswell, 2013). Glaser was influenced by Paul Lazarsfeld, an innovator in the field of quantitative methods (Glaser, 1992; Hallberg, 2006; Walker \& Myrick, 2006) and also Glaser's teacher when he was studying quantitative and qualitative mathematics at Columbia University.

Paul Lazarsfeld and his work on qualitative analysis influenced Glaser's conceptual ideas of grounded theory (Glaser \& Strauss, 1967; Glaser, 1998, 2005). Lazarsfeld's research strategies were similar to those used in the grounded theory process (Martin \& Gynnild, 2011). According to Glaser (2005), Lazarsfeld influenced him with four important methodological contributions to the development of grounded theory: the index formation model to generate concepts; the interchangeability of indicators to generate concepts; constant comparative analysis, and the core variable analysis model. The first two originated directly from Lazarsfeld's work, while the constant comparative analysis technique was discovered and developed by Glaser (Glaser, 2005).

In 1965, Glaser and Strauss worked together on a study of the sociology of illness that resulted in an article entitled "Awareness of Dying" (Glaser \& Strauss, 1965), in which they sought to develop an abstract theory of the interactions between patients and staff in hospitals at the end of life, rather than to a provide a descriptive analysis of events or attitudes (Glaser \& Strauss, 1967). The approach they developed was a systematic method of discovering theory from data involving inductive processes (Glaser \& Strauss, 1967). During this study Glaser and Strauss became aware that the methodology they used was original. "The Awareness of Dying" article provided the first account of grounded theory and marked the introduction of this research approach as an alternative to other more established research methodologies (Elliott \& Lazenbatt, 2005). This article was highly acclaimed, and as such the authors received a lot of attention from the scientific community, which led to their decision to present grounded theory more formally by publishing a book on it (Glaser, 1992).

Two years later, Glaser and Strauss published the methodology for qualitative research that they had developed during the Awareness of Dying study, in the book, Discovery of Grounded Theory: Strategies for qualitative research (Glaser \& Strauss, 1967). They named their new method 'Grounded Theory' and presented this as a new approach to research, developed during their study of dying (Glaser \& Strauss, 1967). This discovery resulted from their attempts to improve the theory-research gap that had not been bridged by studies using logical deductive reasoning as the method of inquiry (Eaves, 2001; Jeon, 2004). Grounded theory was therefore designed to provide an alternative to the verificational research tradition prevalent in sociology at that time (Glaser \& Strauss, 1967). In addition, Glaser and Strauss developed the grounded theory approach in response to the then prevalent view of quantitative research as the predominant model for social science research (Charmaz, 2000).

Glaserand Strauss(1967)found thatqualitative research consisted of detailed description, mostly giving background to quantitative studies but generating little theory. At the same time, quantitative researchers were developing rigorous methods for testing and reproducing facts (Glaser \& Strauss, 1967). Glaser and Strauss (1967) explained that the rationale for grounded theory was to generate and develop theory through interplay with data collected during research projects. They demonstrated how to generate a substantive theory from data originating from reality by using an inductive research method. Consequently, grounded theory has been presented as an inductive research method that aims at generating theory through the 
Henny Suzana : The Origin and Development of Grounded Theory: A Brief History

emergence of that theory from substantive data (Glaser \& Strauss, 1967). This was the beginning of the classical grounded theory methodology (Schreiber \& Stern, 2001).

\section{Evolution of grounded theory}

After the publication of The Discovery of Grounded Theory (1967), Glaser and Strauss continued to work together to conduct many collaborative research projects, and wrote four more books from their study on dying: Time for dying (Glaser \& Strauss, 1968); Anguish: Case study of a dying patient (Glaser \& Strauss, 1970); Status passage (Glaser \& Strauss, 1971), and Chronic illness and the quality of life (Glaser \& Strauss, 1975).

In 1978, Glaser published the advances in grounded theory methodology as Theoretical sensitivity, the purpose of which was to provide practical insights into the methodological processes involved in generating a grounded theory. Glaser (1978) provided step-by-step guidance for conducting the grounded theory process, and for theoretical coding, basic social processes, and theoretical sorting. Nine years later, Strauss published his own text, Qualitative analysis for social sciences (Strauss, 1987), which was intended to make grounded theory more accessible because there was still criticism about Glaser's use of 'abstract terms and dense writing' in Theoretical sensitivity (Charmaz, 2000). However, other writers disagreed with this criticism and continued to recommend Theoretical sensitivity as a good resource for the grounded theory student (MacDonald \& Schreiber, 2001).

In 1990 Strauss and Glaser parted ways when Strauss published Basics of qualitative research: Grounded theory procedures and techniques with Juliet Corbin (Strauss \& Corbin, 1990). Glaser argued that this book misrepresented grounded theory. Moreover, Glaserdisagreed withmany ofthestancestaken by the book, criticising Strauss and Corbin's method for producing description rather than theory, and for imposing preconceived codes on data (Glaser, 1992). Glaser responded with the book Basics of grounded theory: Emergence vs. forcing (Glaser, 1992). Since 1992, Glaser has developed grounded theory alone. The method elaborated by Glaser is often called Classic Grounded Theory or Glaserian Grounded Theory.

\section{Theoretical and philosophical roots of grounded theory}

Grounded theory has its roots in the social sciences (Chenitz \& Swanson, 1986; Crook, 2001; Cutcliffe, 2000; Eaves, 2001; Goulding, 1999; Hutchinson \& Wilson, 2001; Milliken \& Schreiber, 2001). Grounded theory's philosophical origins are attributable, at least in part to symbolic interactionism as developed by School of Sociology Chicago between 1920 and 1950 (Benoliel, 1996; Chenitz \& Swanson, 1986; Glaser \& Strauss, 1967, Glaser, 1998). Symbolic interactions (SI) is a theory about human behaviour (Chenitz \& Swanson, 1986).

An assumption of grounded theory is that people actively shape the worlds in which they live through the process of symbolic interaction, and that life is characterised by variability, complexity, change and process (Glaser, 1992). Symbolic interactionism was developed by Mead (1934) and advanced by Blumer (1969), and represents not only a theory of human behaviour but also an approach to studying the lives, conduct, actions and interactions of humans within societal groups (Annells, 1996; Chenitz \& Swanson, 1986; Blumer, 1969). Symbolic interactionism is concerned with the meaning of events to people and the symbols they use to convey those meanings (Baker, Wuest, \& Stern, 1992). It focuses on the experiential aspects of human behaviour or on how people define events and reality, and on how they act according to their beliefs (Chenitz \& Swanson, 1986). Symbolic interactionism holds that people are in a continual process of interpretation and definition as they move from one situation to another (Eaves, 2001). Blumer (1969) identified three assumptions that underpin symbolic interactionism: firstly, people act and react to things and people on the basis of meanings that these have for them; secondly, meanings stem from interaction with others, and finally, people's meanings are modified through an interpretive process that they use to make sense of and manage their social worlds. Blumer (1969, p. 3) emphasises that meaning 
Henny Suzana : The Origin and Development of Grounded Theory: A Brief History

is central to symbolic interactionism and argues that to ignore the 'meaning of things toward which people act is seen as falsifying the behaviour under study'. Thus, human behaviour is the result of an interpretive process in which people assign meaning to the events and situations that they encounter (Baker et al., 1992). Meaning is one of the major elements in understanding human behaviour, interactions and social process (Goulding, 1999; Jeon, 2004). According to this paradigm, individuals engage in a world which requires reflexive interaction instead of an environmental response (Goulding, 1999). People are purposive in their actions and will act and react to environmental cues, objects and other factors, according to the meaning these hold for them. These meanings evolve from social interaction which is itself symbolic because of the interpretation attached to various forms of communication such as language, gesture, and significant objects (Goulding, 1999). The meanings are modified, suspended or regrouped in the light of changing situations (Schwandt, 1994). Symbolic interactionism emphasises that individuals and groups are active participants in creating meaning within situations (Chenitz \& Swanson, 1986). People, individually and within groups, construct their realities from the symbols around them, through interaction (Cutcliffe, 2000). Through social interactions, human beings become aware of what others are doing or of what they are willing to do (Aldiabat \& Le Navenec, 2011). Using the perspective of symbolic interactionism, grounded theory therefore, provides a means of studying human behaviour and interaction, creating a new perspective and understanding of common behaviour at both an interactional and symbolic level (Chenitz \& Swanson, 1986).

The symbolic interactionism perspective has implications for research because the meaning of the event must be understood from the participants' perspective, and behaviour must be understood at the symbolic and behavioural levels, and examined in interaction (Chenitz \& Swanson, 1986). In addition, Chenitz and Swanson (1986) suggest that this perspective is useful in complex situations, to examine emerging or unresolved social problems. Methodologically, the researcher is required to enter the world of the participants under study to observe and examine the human interactions and interpretations that occur in order to fully understand them (Chenitz \& Swanson, 1986; Goulding, 1999). The researcher examines behaviour in the setting in which it occurs, in terms of social interaction and shared meanings (Chenitz $\&$ Swanson, 1986). In order to understand the phenomenon under study the researcher must be both an observer and a participant (at least in imagination) in the participants' world and further must be a translator of this understanding into the language of the researcher's discipline (Chenitz \& Swanson, 1986). Using these principles as the basic foundation, Glaser and Strauss developed a more defined and systematic procedure for collecting and analysing qualitative data (Glaser, 1998, Glaser \& Holton, 2004; Goulding, 1999). Thus, symbolic interactionism provides a guiding framework for the collection of data about meanings, and how they change through social and physical time and space (Aldiabat \& Le Navenec, 2011; Chenitz \& Swanson, 1986; Glaser, 1978, 1992, 1998).

Grounded theory is based upon assumptions that both knowledge and people are dynamic, and the context facilitates, hinders, or influences human goals and the psychosocial process (Benoliel, 1996). Based on this assumption, grounded theory's main aim is developing and understanding the knowledge of human behaviour-how individuals construct and reconstruct their lives in the light of their experiences, and the meanings they assign to these in order to discover the basic social process (Glaser, 1978; MacDonald \& Schreiber, 2001; Milliken \& Schreiber, 2001). I found in my study that grounded theory has the potential to provide insight into a complex phenomenon, like nurses' pain management practice when caring for hospitalised children experiencing pain (Mediani, 2014). Thus, in grounded theory the researcher needs to comprehend participants' behaviours as they understand them. This can be achieved by learning about participants' interpretation of self in the interaction, and sharing their definition. Symbolic interactionism directs grounded theorists to assume that meaning is made 
Henny Suzana : The Origin and Development of Grounded Theory: A Brief History

and constantly changed through interaction, and to become embedded in social context (Wuest, 2012).

\section{Conclusion}

Grounded theory is a natural product of post-positivist movement and symbolic interactionism. Symbolic interactionism is the source of grounded theory's foundational assumptions and has contributed to the philosophy guiding the development of grounded theory methodology. The epistemological underpinning of grounded theory makes it important in nursing research, which is premised on an interpersonal process between nurses and their patients (McCann $\&$ Clark, 2003). A grounded theory approach is applicable to a wide variety of issues relevant to clinical practice and can make valuable contribution to the development of a theoretical base for clinical nursing practice (Elliott \& Lazenbatt, 2005; Mediani, 2017).

\section{References}

Aldiabat, K.M., \& Le Navenec, C-L. (2011). Philosophical roots of classical grounded theory: Its foundations in symbolic interactionism. The Qualitative Report, 16(4), 1063-1080. Retrieved 20 September 2012 from http://www.nova.edu/sss/QR?QR16-4/ aldiabat.pdf.

Annells, M. (1996). Grounded theory method: Philosophical perspective, paradigm of inquiry, and postmodernism. Qualitative Health Research, 6(3), 379-393. doi: $10.1177 / 104973239600600306$.

Artinian, B.M. (2009). An overview of Glaserian Grounded Theory. In B.M. Artinian, T. Giske, \& P.H. Cone, Glaserian Grounded Theory in nursing research: Trusting emergence (pp. 3-17). New York: Springer Publishing.

Baker, C., Wuest, J., \& Stern, P. (1992). Method slurring: The grounded theory/ phenomenological example. Journal of Advanced Nursing, 17(1), 1355-1360. doi: 10.1111/j.1365-2648.1992.tb01859.x.

Benoliel, J.Q. (1996). Grounded theory and nursing knowledge. Qualitative Health Research, 6(3), 406-428. doi: $10.1177 / 104973239600600308$.

Blumer, H. (1969). Symbolic interaction. Prentice Hall, Englewood Cliff, NJ.

Charmaz, K. (2000). Constructivist and objectivist grounded theory. In N.K. Denzin \& Y. Lincoln (Eds), Handbook of Qualitative Research (2nd ed., pp. 509-535). Thousand Oaks, CA: Sage.

Chenitz, W.C., \& Swanson, J.M. (1986). Qualitative research using grounded theory. In Chenitz W.C, Swanson, J.M (Eds), From practice to grounded theory. Menlo Park, Addison-Wesley.

Creswell, J.W. (2013). Qualitative inquiry \& research design: Choosing among five approaches (3rd ed.). Sage, Los Angeles.

Crook, D.L. (2001). The importance of symbolic interaction in grounded theory research on women's health. Health Care for Women International, 22(1-2), 11-27. doi: $10.1080 / 073993301300003054$.

Cutcliffe, J.R. (2000). Methodological issues in grounded theory. Journal of Advanced Nursing, 31(6), 1476-1484. doi: 10.1046/j.1365-2648.2000.01430.x.

Eaves, Y.D. (2001). A synthesis technique for grounded theory data analysis. Journal of Advanced Nursing, 35(5), 654-663. doi: 10.1046/j.1365-2648.2001.01897.x.

Elliott, N., \& Lanzenbatt, A. (2005). How to recognise a 'quality' grounded theory research Study. Australian Journal of Advanced Nursing, 22(3), 48-52. PMID: 16499241 [PubMed-indexed for MEDLINE].

Glaser, B.G. (1978). Theoretical sensitivity: Advances in the methodology of grounded theory. Mill Valley, CA: Sociology Press.

Glaser, B.G. (1992). Emergence vs. forcing: 
Henny Suzana : The Origin and Development of Grounded Theory: A Brief History

Basis of grounded theory analysis. Mill Valley, CA: Sociology Press.

Glaser, B.G. (1998). Doing Grounded Theory: Issues and discussions. Mill Valley, CA: Sociology Press.

Glaser, B.G. (2005). The Grounded Theory Perspective III: Theoretical coding, Mill Valley, CA: Sociology Press.

Glaser, B.G., \&Holton, J.(2004). Remodelling grounded theory. Forum: Qualitative Social Research, 5(2). Retrieved April 2011 from www.qualitativeresearch.net/index.php/fqs/ article/view/.

Glaser, B.G., \& Strauss, A.L. (1965). Awareness of dying. Chicago: Aldine.

Glaser, B.G., \& Strauss, A.L. (1967). The discovery of grounded theory: Strategies for qualitative research. Transaction Publishers. Chicago, IL: Aldine De Gruyter.

Glaser, B.G., \& Strauss, A.L. (1968). Time for dying. Chicago: Aldine.

Glaser, B.G., \& Strauss, A.L. (1970). Anguish: A case history of a dying trajectory. Mill Valley, CA: Sociology Press.

Glaser, B.G., \& Strauss, A.L. (1971). Status passage: A formal theory. Chicago: Aldine.

Glaser, B.G., \& Strauss, A.L. (1975). Chronic illness and the quality of life. St. Louis, MO: G.V. Mosby.

Goulding, C. (1999). Grounded theory: Some reflections on paradigm, procedures and misconceptions. Working Paper Series June 1999. Wolverhampton, UK, University, ISSN 1363-6839.

Hallberg, L. (2006). The 'core category' of groundedtheory:Making constantcomparison. International Journal of Qualitative Studies on Health and Well-being, 1(3), 141-148. doi: $10.1080 / 1782620600858399$.

Hutchinson, S.A., \& Wilson, H.S. (2001). Grounded theory: The method. In P. L.
Munhall, (Ed), Nursing research, a qualitative perspective (3rd ed., pp. 209-245). Jones and Bartlett Publishers, Sudbury, Canada.

Jeon, Y.H. (2004). The application of grounded theory and symbolic interactionism. Scandinavian Journal of Caring Sciences, 18(3), 249-256. doi: 10.1111/j.14716712.2004.00287.x.

Jones, M. (2005). "Lights,...Action... Grounded Theory": Developing an understanding for the management of film production". Rhyzome, 1(1): In Print.

MacDonald, M., \& Schreiber, R. (2001). Constructing and deconstructing: Grounded theory in a postmodern world. In R. Schreiber \& P. N. Stern (Eds.), Using grounded theory in nursing (pp. 35-54). New York: Springer.

Martin, V., \& Gynnild, A. (2011). Grounded theory: The philosophy, method, and work of Barney Glaser. Boca Raton, FL: Brown Walker Press.

McCann, T.V., \& Clark, E. (2003). Grounded theory in nursing research: Part 2-critique. Nurse Researcher, 11(2), 19-28. PMID: 14708426 [PubMed-indexed for MEDLINE].

Mead, G. (1934). Mind, self, and society. Chicago, IL: The University of Chicago Press.

Mediani, H.S. (2017) An Introduction to Classical Grounded Theory. SOJ Nur Health Care 3(3): 1-5. Retrieved from https:// symbiosisonlinepublishing.com/nursinghealthcare/nursing-health-care35.pdf.

Mediani. (2014). Indonesian nurses management of pain: A grounded theory study (Ph.D Thesis). Faculty of Health Curtin University, Australia.

Milliken, P.J., \& Schreiber, R.S. (2001). Constructing and deconstructing: Grounded theory in a postmodern world. In R. Schreiber \& P.N. Stern (Eds), Using grounded theory in nursing (pp. 35-54). New York: Springer. 
Henny Suzana : The Origin and Development of Grounded Theory: A Brief History

Pole, C., \& Lampard, R. (2002). Practical Social Investigation-Qualitative and Quantitative Methods in Social Research. Harlow, Essex, Pearson Education Limited.

Schreiber, R., \& Stern, P.N. (2001). In R.S. Schreiber \& P.N. Stern (Eds), Using grounded theory in nursing (pp. 35-54). New York: Springer.

Schwandt, T.A. (1994). Constructivist, interpretivist approaches to human inquiry. In N. K.

Strauss, A.L. (1987). Qualitative analysis for social scientists. Cambridge University Press, Cambridge.
Strauss, A.L., \& Corbin, J.M. (1990). Basics of qualitative research: Grounded theory procedures and techniques. London: Sage Publications.

Walker, D., \& Myrick, F. (2006). Grounded theory: An exploration of process and procedures. Qualitative Health Research, 16(4), 547-559. doi: $10.1177 / 1049732305285972$.

Wuest, J. (2012). Grounded theory: The method. In P.L. Munhall (Ed.). Nursing research: A qualitative perspective (5th ed.) (pp. 225-256). Jones and Bartlett Publishers. Inc. United States. 